\title{
Microbial Population and Fermentation Characteristic in Response to Sapindus rarak Mineral Block Supplementation
}

\author{
S. Suharti ${ }^{a}$, A. Kurniawati ${ }^{b}$, D. A. Astuti ${ }^{a}$, \& E. Wina ${ }^{b}$ \\ aDepartment of Nutrition and Feed Technology, Faculty of Animal Science, Bogor Agricultural University \\ Jln. Agatis, Kampus IPB Darmaga Bogor 16680 \\ bLivestock Research Centre, Ministry of Agriculture \\ Jl. Veteran III, Desa Banjarwaru, Ciawi - Bogor 16002 \\ (Received 19-03-2010; accepted 23-12-210)
}

\begin{abstract}
This experiment was conducted to evaluate the effect of supplementation with lerak extract combined with mineral block on protozoal and bacterial population, and fermentation characteristic in vitro. The experimental design was completely randomized block design with 3 treatments and 4 replications. Control diet was a substrate that consisted of concentrate, forage and feed block with ratio $50: 48: 2$, respectively. The treatments as a substrate were: control diet (C), $C+0.09 \%$ lerak extract, and $\mathrm{C}+\mathbf{0 . 1 8 \%}$ lerak extract from the total ration. Variables observed were protozoal and bacterial population, dry matter and organic matter degradability, $\mathrm{N}-\mathrm{NH}_{3}$ and total volatile fatty acid (VFA) concentration. Data were analyzed using analysis of variance (ANOVA). The result showed that there were no significant effect $(P>0.05)$ for all parameter measured with lerak extract supplementation up to $0.18 \%$ in the presence of mineral block. However, supplementation of lerak extract $0.18 \%$ only slightly reduced protozoal numbers but tended to increase bacterial numbers. Dry matter and organic matter degradability and concentration of $\mathrm{N}-\mathrm{NH}_{3}$ were similar among treatments. Volatile fatty acids profile changed which propionate tended to increase and acetate tended to decrease and ratio of acetate to propionate tended to decrease. In conclusion, addition of lerak extract up to $0.18 \%$ from total ration in the presence of mineral block was not yet effective to depress protozoal population, but could modify fermentation characteristic in vitro.
\end{abstract}

Key words: Sapindus rarak, saponin, ruminal fermentation, digestibility, gas production

\section{INTRODUCTION}

The ruminants production in developing countries is limited by several factors, such as: management, feed and animal health. Farmers usually feed their animals low quality of forage that contains high lignocellulose and cellulose, and is deficient in nitrogen (Wina et al., 2005b). There are several strategies to overcome this problem such as by manipulating ruminal bacteria to modify rumen fermentation to enhance efficiency of microbial protein synthesis by using defaunating agent.

It has been known that, the activity of ruminal bacteria to digest feed fiber usually altered by protozoa. This is due to the predation of some bacteria by protozoa (Gutierrez, 2007). On the other hand, protozoa also help the host animals to digest feed fiber (Hart et

*Corresponding author:

Department of Nutrition and Feed Technology,

Faculty of Animal Science, Bogor Agricultural University

Jln. Agatis, Kampus IPB Darmaga Bogor 16680

E-mail: sri_suharti@ipb.ac.id al., 2008). However, according to the reports of some research showed that the presence of protozoa has more disadvantages than the advantages (Eugene et al., 2004). In the rumen ecosystem, protozoa are also host for methanogenic bacteria in the hydrogen transfer process. Methanogenic bacteria use the $\mathrm{H}_{2}$ produced by protozoa and converted into $\mathrm{CH}_{4}$ (methane). Therefore, suppression of protozoa population has been suggested to be an alternative way of reducing methane production.

Some research has also been conducted to evaluate the potential of secondary plant constituents as natural agents to manipulate rumen fermentation (Wallace $e t$ al., 2002; Hart et al., 2008). Besides tannins, saponins are the most widely occurring compounds that are being investigated as rumen manipulators. These compounds could be beneficial or detrimental to the ruminant depending on their concentration and structure. Saponins or saponin-like substances have been reported to have potential to suppress growth of protozoa and change fermentation patterns in the rumen system (Wina et al., 2005a). Saponins and tannins have been reported to modulate ruminal fermentation and improve nutrient utilization in ruminants (Benchaar et al., 2008). Decreased numbers of 
ciliate protozoa will enhance the flow of microbial protein from the rumen, increase efficiency of feed utilization, and decrease methanogenesis. Saponins also affect both number and species ruminal bacterial composition through specific inhibition, or selective enhancement of growth of individual species.

Whole lerak (Sapindus rarak) fruit extract contains high level of saponin than can be used as defaunating agent and to improve animal performance. The extract of S. rarak fruit pericarp has been proved to increase sheep average daily gain by $40 \%$ (Wina et al., 2005c). However, limited reports on the use of whole lerak fruit (including seed) extract combined with mineral block for cattle and its effect on gas production.

Therefore, this research was conducted to analyse the effect of whole lerak fruit extract on protozoal and bacterial population, dry and organic matter digestibil-

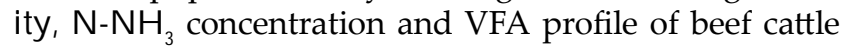
rumen in vitro.

\section{MATERIALS AND METHODS}

\section{Preparation of Whole Lerak Fruit Extract}

Whole lerak fruits (including seed) bought from Central Java, Indonesia were dried in the oven at $60^{\circ} \mathrm{C}$ until $90 \%$ dry matter. After drying, the whole fruits were ground immediately. Lerak meal was soaked overnight in methanol 100\% (1:4, w/ $)$. After the particles settled, the extract was separated and the extraction was repeated with an equal volume of fresh methanol. The methanol fractions were then pooled and evaporated in a rotary evaporator. The residual fraction was freeze dried and kept in airtight bags until further use.

\section{Rumen Fluid and Experimental Design}

Rumen fluid for this experiment was collected just before morning feeding from a ruminally fistulated beef cattle (Ongole breed). The cattle were fed a diet consisting of native grass $(50 \%)$ and commercial concentrate (50\%) twice a day at 08.00 and 16.00 hours. The cattle were kept in the individual animal house. The rumen fluid was filtered through a double layer of cheesecloth for in vitro experiment. The in vitro fermentation was conducted in the Microbiology Laboratory, Department of Nutrition and Feed Technology, Faculty of Animal Science, Bogor Agricultural University.

Substrate for in vitro rumen fermentation was a mixture of concentrate feed, dried milled native grass, and block feed (50:48:2 $\mathrm{w} / \mathrm{w} / \mathrm{w})$. The concentrate mix (self mixing) comprised of soybean meal, coconut cake meal, cassava waste, wheat pollard, molasses, dicalcium phosphate (DCP), $\mathrm{NaCl}$ and $\mathrm{CaCO}_{3}$. Native grass was harvested from the surrounding area of Bogor Agricultural University farm (Indonesia), dried in the oven and milled. The proximate analysis of concentrate and native grass are shown in Table 1.

The in vitro experiment was assigned in completely randomized block design consisting of 3 treatments and 4 replications. A mixture of concentrate, grasses, and mineral block was used as substrate $(50: 48: 2, \mathrm{w} / \mathrm{w} / \mathrm{w})$ with three levels of lerak extract as treatments i.e., 0 , 0.09 , and $0.18 \%(\mathrm{w} / \mathrm{w})$ from total ration.

\section{In Vitro Fermentation (Tilley \& Terry, 1963)}

The substrate $(500 \mathrm{mg})$ was put into a $100 \mathrm{ml}$ fermentation tube and added by $40 \mathrm{ml}$ of McDougall buffer and $10 \mathrm{ml}$ of rumen fluid. The McDougal buffer, per 6 liters containing $\mathrm{NaHCO}_{3}(58,8 \mathrm{~g}), \mathrm{Na}_{2} \mathrm{HPO}_{4} .7 \mathrm{H}_{2} \mathrm{O}(42 \mathrm{~g})$ $\mathrm{KCL}(3,42 \mathrm{~g}), \mathrm{NaCl}(2,82 \mathrm{~g}), \mathrm{MgSO}_{4} .7 \mathrm{H}_{2} \mathrm{O}(0,72 \mathrm{~g}), \mathrm{CaCl}_{2}$ $(0,24 \mathrm{~g})$ and $\mathrm{H}_{2} \mathrm{O}$. The mixture was stirred and flushed with $\mathrm{O}_{2}$-free carbon dioxide and the tubes were then sealed with a rubber cork fitted with the gas release valve. All fermentation tube were incubated in a shaker waterbath at $39^{\circ} \mathrm{C}$ for $4 \mathrm{~h}$ for protozoa, bacteria, total volatile fatty acids (VFA) and $\mathrm{N}-\mathrm{NH}_{3}$ measurement and $48 \mathrm{~h}$ for digestibility of dry matter and organic matter measurement with pepsin treatment.

\section{Protozoal and Bacterial Counts}

At $4 \mathrm{~h}$ incubation, $1 \mathrm{ml}$ aliquots was taken from each fermentation tube for analysis of protozoal and bacterial population. The contents of the fermentation tube were mixed properly and $1 \mathrm{ml}$ of the sample was mixed with $1 \mathrm{ml}$ methyl green formal dehyde saline solution containing 35\% formaldehyde, distilled water, methylgreen and $\mathrm{NaCl}$ (Ogimoto \& Imai, 1981). The stained sample was kept at room temperature and protozoal population were counted directly using Counting chamber $(0,1 \mathrm{~mm})$ with microscope (40x). Protozoal population calculated using formula:

$$
\begin{aligned}
& \text { Protozoal population }=\frac{1 \times 1000 \times \mathrm{C} \times \mathrm{DF}}{0,1 \times 0,065 \times 16 \times 5} \\
& \mathrm{C}=\text { protozoal number } \\
& \mathrm{DF}=\text { dilution factor }(=2)
\end{aligned}
$$

Table 1. Proximate composition of native grass, concentrate, mineral block and total ration (\% dry matter)

\begin{tabular}{lcrr}
\hline Nutrient & $\begin{array}{c}\text { Native grass } \\
(\mathrm{G})\end{array}$ & $\begin{array}{c}\text { Concentrate } \\
(\mathrm{C})\end{array}$ & \multicolumn{2}{c}{$\begin{array}{c}\text { Mineral block } \\
(\mathrm{B})\end{array}$} & 41.89 \\
$(\mathrm{C}: \mathrm{G}: \mathrm{B}=50: 48: 2)$ & 6.39 \\
Ash & 9.37 & 19.07 & 21.53 \\
Crude protein & 8.98 & 2.99 & 0.74 \\
Ether extract & 1.03 & 12.20 & 4.00 \\
Crude fiber & 41.14 & 2.00 & 26.05 \\
\hline
\end{tabular}


To estimate the population of bacteria was determined using serial dilution method at 4 incubation. Rumen aliquots of $0.05 \mathrm{ml}$ was added in the $4.95 \mathrm{ml}$ dilution medium. Serial dilution were $10^{-2}, 10^{-4}, 10^{-6}$ and $10^{-8}$ with brain heart infusion (BHI) medium (GérardChampod et al., 2009). Total bacteria colony forming unit (CFU) were determined according to the formula:

$$
\begin{aligned}
& \text { Bacterial population }=\frac{\text { colony number }}{0,05 \times 10^{x} \times 0,1} \\
& x=\text { dilution factor }
\end{aligned}
$$

\section{Estimation of VFA and N-NH $\mathrm{N}_{3}$ Concentration and in Vitro Degradability}

Measurement of total VFA was done using steam distillation method (General Laboratory Procedures, 1966) and $\mathrm{N}^{-\mathrm{NH}_{3}}$ concentration using micro diffusion method (Conway, 1962). Molar proportion of VFA was analyzed by gas chromatography. To determine the in vitro dry matter and organic matter degradability (IVDMD and IVOMD), the content of the fermentation tube incubated during $48 \mathrm{~h}$ was transferred into a tube and centrifuged at 2,500 rpm for $20 \mathrm{~min}$ at room temperature. The supernatants were discarded and the residues were passed through a filter paper (Whatman no. 41). The residue of each fermentation tube was dried to the constant weight at $105{ }^{\circ} \mathrm{C}$ for $24 \mathrm{~h}$ to determine IVDMD. Thus, the sample was ashed at $450-600{ }^{\circ} \mathrm{C}$ for $6 \mathrm{~h}$ to determine IVOMD (Tilley \& Terry, 1963).

\section{Statistical Analysis}

Statistical analysis of the data was carried out by one-way ANOVA (Steel \& Torrie, 1995).

\section{RESULTS AND DISCUSSION}

\section{Protozoal and Bacterial Numbers}

There were no significant effects of lerak extracts supplementation on different protozoal and bacterial numbers in the in vitro fermentation test (Table 2). However, inclusion of lerak extracts up to level $0.18 \%$ in the mineral block only slightly reduced protozoal numbers, whereas bacterial numbers tended to increase. Whole lerak fruit (including seed) of methanol extracted have been found to contain high saponin up to 81.5 (Suharti et al., 2009). The inhibitory effect of these extract

Table 2. Protozoal and bacterial population of in vitro rumen fermentation supplemented by lerak (Sapindus rarak) extract at $4 \mathrm{~h}$ incubation

\begin{tabular}{lcc}
\hline \multirow{2}{*}{ Diet } & \multicolumn{2}{c}{ Microbial population (Log CFU) } \\
\cline { 2 - 3 } & Protozoa & Total bacteria $^{*}$ \\
\hline Control diet $(\mathrm{C})$ & $3.90 \pm 0.24$ & 8.04 \\
C $+0.09 \%$ lerak extract & $3.88 \pm 0.45$ & 9.21 \\
$\mathrm{C}+0.18 \%$ lerak extract & $3.55 \pm 0.17$ & 10.01 \\
\hline
\end{tabular}

*) no replication. on protozoa could be due to their saponin content. Decreased protozoal counts with supplementation of saponins rich extract (Kamra et al., 2000) or saponin rich forages (Ivan et al., 2004 or fruits (Hess et al., 2003) have been reported. Saponins possibly bind with sterol of cell membrane of protozoa and change the permeability of cell membrane.

Lerak extract inclusion stimulated bacterial population might be due to the reduction of protozoal population. Muetzel et al. (2003) reported that saponins from Sesbania pachycarpa leave also have defaunating effect and may have also contributed to the increased microbial efficiency due to a decrease in protozoal predation. Furthermore, Ozutsumi et al. (2006) also reported that there were higher numbers of plasmid copies of Prevotella ruminicola, Ruminococcus albus, Ruminococcus flavefaciens, in the unfaunated than in the faunated rumens. In contrast, Fibrobacter succinogenes was higher in the faunated than in the unfaunated rumens. Although it is well known that the absence of protozoa brings about an increase in the bacterial population, it was clarified here that the absence of protozoa exerted differential effects on the populations of cellulolytic bacteria in cattle rumen.

\section{Degradability, $\mathrm{N}-\mathrm{NH}_{3}$ and VFA}

In vitro degradability of dry matter (IVDMD) and organic matter (IVOMD) was not change by the addition of lerak extract (Table 3). Furthermore, there were suppression in degradability varied between $3 \%$ and $4 \%$ compared to the control. It seems that lerak extract had some secondary metabolites which might have detrimental effect to the fermentation activity and reduced degradability of feed. Lila et al. (2003) also observed that sarsaponin reduced degradability in vitro of hay plus concentrate after $24 \mathrm{~h}$ of incubation. A depression in feed degradability by lerak extract could be due to phenolic compounds such as tannins and tannic acids. Tannins have been implicated for their inhibitory effect on feed digestion, microbial population and enzymes activity (McSweeney et al., 2001). Moreover, Hristov et al. (1999) reported that the extent of ruminal degradability of dietary dry matter was not affected by saponins treatment, although the rate of degradation of insoluble dry matter was increased with sarsaponin. They also explained that a portion of the ruminally administered sarsaponin could pass out of the rumen with the liquid phase of ruminal contents and, upon reaching the intestine, could affect the postruminal digestibility of nutrients. In a subsequent study, Wang et al. (2000) reported that steroidal saponins inhibited the ruminal cellulolytic bacteria (F. succinogenes, R. flavefaciens, and R. albus) and fungi (Neocallimastix frontalis and Piromyces rhizinflata).

Total VFA concentration tended to increase with lerak extract supplementation (Table 3). Molar proportion of acetate tended to decrease but propionate and butyrate tended to increase, whereas the molar proportion of valerate was unchanged. There was a decrease in acetate to propionate ratio due to addition of the lerak as compared to control. Increase in propionate and decrease in acetate and consequently decreased in acetate 
Table 3. Degradability, $\mathrm{N}-\mathrm{NH}_{3}$ and VFA of in vitro rumen fermentation supplemented by lerak (Sapindus rarak) extract

\begin{tabular}{lrrr}
\hline & \multicolumn{3}{c}{ Level of lerak extract } \\
\cline { 2 - 4 } Parameter & \multicolumn{1}{c}{$0 \%$} & $0.09 \%$ & $0.18 \%$ \\
\hline IVDMD (\%) & $67.70 \pm 1.76$ & $65.19 \pm 2.17$ & $64.62 \pm 1.30$ \\
IVOMD (\%) & $66.13 \pm 1.81$ & $63.98 \pm 1.17$ & $63.65 \pm 0.96$ \\
Total VFA (mM) & $153.42 \pm 29.00$ & $170.26 \pm 43.08$ & $184.68 \pm 33.35$ \\
N-NH3 (mM) & $16.31 \pm 2.36$ & $15.85 \pm 3.15$ & $16.00 \pm 3.18$ \\
Molar proportion of VFA (\%)* & & & 60.39 \\
- Acetate (A) & 64.58 & 62.76 & 24.01 \\
- Propionate (P) & 21.44 & 23.01 & 13.13 \\
- Butyrate & 11.70 & 12.54 & 0.94 \\
- Valerate & 0.89 & 0.86 & 2.52 \\
- A:P ratio & 3.01 & 2.73 & \\
\hline
\end{tabular}

*) no replication

and propionate ratio by lerak extract could be due to the presence of saponins and its inhibitory effect on protozoa, which is in agreement with previous studies (Wang et al., 2000; Lila et al., 2003). The reduced protozoal numbers is sometimes associated with the increase in propionate and decrease in A:P ratio (Hess et al., 2003; Machmuller et al., 2003). A decrease in molar proportion of acetate and increase butyrate was consistent with the results of the in vivo study. Hristov et al. (1999) found the effect of sarsaponin on propionate concentration in the rumen was persistent over the course of sampling and was evident even before the daily dose of sarsaponin was introduced in the rumen.

Concentration of ruminal $\mathrm{N}-\mathrm{NH}_{3}$ did not change with the addition of lerak extract (Table 3). This result is in contrary with the previous report that showed a reduction in ruminal ammonia concentrations when saponin from Enterolobium cyclocarpum foliage fed to the sheep (Ivan et al., 2004). A major source of ruminal ammonia is proteolysis of bacterial protein, occurring as a result of ingestion of ruminal bacteria by protozoa. Although saponins have pronounced antiprotozoal activity, but inclusion of lerak extract up to $0.18 \%$ only slight reduced protozoal numbers and did not affect ruminal ammonia concentration. Saponins and saponincontaining plants also improved protein flow from the rumen, but this appears to be mediated mainly by suppressing ciliate protozoa (Wina et al., 2005c).

\section{CONCLUSION}

Addition of lerak extract up to $0.18 \%$ from total ration was not yet effective to depress protozoal population, but could modify fermentation characteristic in vitro.

\section{ACKNOWLEDGEMENT}

This research was supported by "Payung Strategis 2008 Research Grant" which provided by LPPM, Bogor Agricultural University.

\section{REFERENCES}

Benchaar C., T. A. McAllister, \& P. Y. Choulnard. 2008. Digestion, ruminal fermentation, ciliate protozoal populations, and milk production from dairy cows fed Cinnamaldehyde, Quebracho condensed tannin, or Yucca schidigera saponin extracts. J. Dairy Sci. 91: 4786-4777.

Conway, E. J. 1962. Microdiffusion Analysis and Volumetric Error. 5th ed. Crosby Lockwood, London.

Eugene M., H. Archimede, B. Michalet-Doreau, \& G. Fonty. 2004. Effects of defaunation on microbial activities in the rumen of rams consuming a mixed diet (fresh Digitaria decumbens grass and concentrate. Anim. Res. 53: 187-200.

General Laboratory Prosedures. 1966. Department of Dairy Science. University of Wisconsin, Madison.

Gérard-Champod M., S. Blanquet-Diot, L. Mazuranok, \& M. Alric. 2009. Enumeration of some cultivable bacterial groups and characterization of some abiotic variables in the jejunoileal content of Prim'Holstein veal calves. J. Anim. Sci. 87: 1664-1675.

Gutierrez, J. 2007. Observations on bacterial feeding by the rumen ciliate Isotricha prostoma. J. Eukaryotic Microb. 5:122-126.

Hart, K. J., D. R. Y'ãnez-Ruiz, S. M. Duval, N. R. McEwan, \& C. J. Newbold. 2008. Plant extracts to manipulate rumen fermentation. Anim. Feed Sci. Tech. 147:8-35.

Hess, H. D., M. Kreuzer, T. E. Diaz, C. E. Lascano, J. E. Carulla, \& C. R. Solvia. 2003. Saponin rich tropical fruits affect fermentation and methanogenesis in faunated and defaunated fluid. Anim. Feed Sci. Tech. 109:79-94.

Hristov, A. N., T. A. McAllister, F. H. Van Herk, K.-J. Cheng, C. J. Newbold, \& P. R. Cheeke. 1999. Effect of Yucca schidigera on ruminal fermentation and nutrient digestion in heifers. J. Anim. Sci. 77:2554-2563.

Ivan, M., K. M. Koenig, B. Teferedegne, C. J. Newbold, T. Entz, L. M. Rode, \& M. Ibrahim. 2004. Effects of the dietary Enterolobium cyclocarpum foliage on the population dynamics of rumen ciliate protozoa in sheep. Small Ruminant Research: 52:81-91.

Kamra, D. N., R. Singh, N. Agarwal, \& N. N. Pathak. 2000. Soapnut (Reetha) as natural defaunating agent - its effect on rumen fermentation and in sacco degradability of jowar hay in buffaloes. Buffalo J. 16:99-104.

Lila, Z. A., N. Mohammed, S. Kanda, T. Kamada, \& H. Itabashi. 2003. Effect of sarsaponin on rumen fermentation with particular reference to methane production in vitro. J. Dairy Sci. 86:3330-3336. 
Machmuller, A., C. R. Soliva, \& M. Kreuzer. 2003. Methane suppressing effect of myristic acid in sheep as affected by dietary calcium and forage proportion. Br. J. Nutr. 90, 529-540.

McSweeney, C. S., B. Palmer, D. M. McNeill, \& D. O. Krause. 2001. Microbial interactions with tannins: nutritional consequences for ruminants. Anim. Feed Sci. Tech. 91:83-93.

Muetzel, S., E. M. Hoffmann, \& K. Becker. 2003. Supplementation of barley straw with Sesbania pachycarpa leaves in vitro: effects on fermentation variables and rumen microbial population structure quantified by ribosomal RNA-targeted probes. Br. J. Nutr. 89:445-453.

Ogimoto, K. \& S. Imai. 1981. Atlas of Rumen Microbiology. Japan Science. Societes Press, Tokyo.

Ozutsumi, Y, K. Tajima, A. Takenaka, \& H. Itabashi. 2006. Real-Time PCR detection of the effects of protozoa on rumen bacteria in cattle. Curr. Microbiol. 52:158-162.

Suharti, S., D. A. Astuti, E. Wina, \& B. Haryanto. 2009. Kecernaan nutrien dan performa produksi sapi potong peranakan ongole (PO) yang diberi tepung lerak (Sapindus rarak) dalam ransum. Jurnal Ilmu Ternak dan Veteriner 14:200-207.

Steel, R. G. D. \& J. H. Torrie. 1995. Principles and Procedur of Statistic. A Biometrical Approach. $2^{\text {nd }}$ Ed. Mc.Graw Hill International Book Co., London.
Tilley, J. M. A. \& R. A. Terry. 1963. A two stage technique for the in vitro digestion of forage. J. British Grassland Soc. 18:104-111.

Wallace, R. J., N. R. McEwan, F. M. McIntosh, B. Teferedegne, \& C. J. Newbold. 2002. Natural products as manipulators of rumen fermentation. J. Anim. Sci. 15:1458-1468.

Wang, Y., T. A. McAllister, L. J. Yanke, \& P. R. Cheeke. 2000. Effect of steroidal saponin from yucca schidigera extract on ruminal microbes. J. Appl. Microbiol. 88:887-896.

Wina, E., S. Muezel, E. Hoffman, H. P. S. Makkar, \& K. Becker. 2005a. Saponins containing methanol extract of sapindus rarak affect microbial fermentation, microbal activity and microbial comunity structure in vitro. Anim. Feed Sci. and Tech. 121:159-174.

Wina, E., S. Muezel, E. Hoffman, H. P. S. Makkar, \& K. Becker. 2005b. The impact of saponin-containing plant materials on ruminant production - A Review. J. Agric. Food Chem. 53: 8093-8015.

Wina, E., S. Muetzel, \& K. Becker. 2005c. The dynamics of major fibrolytic microbes and enzyme activity in the rumen in response to short-and long-term feeding of Sapindus rarak saponins. J. Appl. Microbiol. 100: 114-122. 